\title{
HIDROLISIS ENZIMATIK KITOSAN DENGAN KOMBINASI ENZIM ENDO-GLUCANASE DAN CELLOBIOHYDROLASE
}

\author{
Nur Rokhati' ${ }^{1)}$, Bambang Pramudono'), Titik Istirokhatun ${ }^{2)}$, Mohammad Sulchan ${ }^{3)}$, Dyah \\ Ayu Kresnianingrum ${ }^{1)}$, Luthfi Kurnia Dewi ${ }^{1)}$ \\ ${ }^{1)}$ Jurusan Teknik Kimia, Fakultas Teknik Universitas Diponegoro \\ Jl. Prof. Soedarto, SH, Tembalang, Semarang 50275, Telp. (024)7460058 \\ ${ }^{2)}$ Jurusan Teknik Lingkungan, Fakultas Teknik Universitas Diponegoro \\ Jl. Prof. Soedarto, SH, Tembalang, Semarang 50275, Telp. (024) 76480678 \\ ${ }^{3)}$ Program Studi Ilmu Gizi, Fakultas Kedokteran Universitas Diponegoro \\ Jl. Prof. Soedarto, SH, Tembalang, Semarang 50275, Telp. (024) 8661396 \\ ${ }^{*}$ Penulis korespondensi : nur_r81@undip.ac.id
}

\begin{abstract}
CHITOSAN ENZYMATIC HYDROLYSIS USING A COMBINATION OF ENDOGLUCANASE AND CELLOBIOHYDROLASE. Chitosan is very promising in various fields including medicine, pharmacology, and the food industry. However, the application of this polysaccharide is limited by its high molecular weight resulting in its low solubility in aqueous media. In this respect, the chitosan with shorter chain length, display a reduced viscosity and are soluble in aqueous media at $\mathrm{pH}$ values close to neutrality. The aim of this study is the hydrolysis of chitosan to obtain a low molecular weight chitosan using enzymes endo-glucanase and cellobiohydrolase. The hydrolysis of chitosan was carried out under a temperature of $40^{\circ} \mathrm{C}$ and $\mathrm{pH}$ 5. Chitosan degradation was monitored by the analysis of reducing sugars and viscosity, whereas the chemical characterization of chitosan is done by using test FTIR (infrared spectroscopy). The results showed that enzyme treatment resulted in a substantial loss in viscosity of the chitosan solution shows depolymerization. Depolymerization using endo-glucanase took place very quickly during the initial 15 minutes. The rate of viscosity decrease on chitosan degradation using cellobiohydrolase is lower than using endo-glucanase. When the reaction time was 4 h, the lowest viscosity is showed by cellobiohydrolase, and the highest solubility is showed by combination of endo-glucanase and cellobiohydrolase.
\end{abstract}

Keywords: endo-glucanase; cellobiohydrolase; chitosan; hydrolysis

\begin{abstract}
Abstrak
Kitosan dapat dimanfaatkan di berbagai bidang seperti kedokteran, farmasi dan industri makanan. Aplikasi kitosan sering dibatasi oleh berat molekul kitosan yang tinggi sehingga viskositasnya tinggi dan kelarutannya rendah. Kitosan dengan rantai polimer pendek, akan mempunyai viskositas rendah, dan mudah larut pada larutan/air dengan pH mendekati netral. Penelitian ini bertujuan untuk menghidrolisis kitosan secara enzimatis menggunakan enzim endo-glucanase dan cellobiohydrolase. Hidrolisis kitosan dilakukan pada suhu $40{ }^{\circ} \mathrm{C}$ dan $\mathrm{pH}$ 5. Degradasi kitosan dipantau melalui analisa gula reduksi dan viskositas, sedangkan karakterisasi kimia kitosan dilakukan dengan menggunakan uji FTIR (infra red spectroscopy). Hasil penelitian menunjukkan bahwa hidrolisis enzimatis kitosan dapat menyebabkan terjadinya penurunan berat molekul yang ditandai dengan adanya penurunan viscositas larutan kitosan. Pada 15 menit awal hidrolisis terjadi penurunan viskositas yang sangat besar. Laju penurunan viskositas enzim cellobiohydrolase lebih rendah dibanding dengan enzime endo-glucanase. Setelah waktu reaksi 4 jam, viskositas terendah diperoleh pada enzime cellobiohydrolase, sedangkan kelarutan tertinggi diperoleh pada kombinasi enzime endo-glucanase dan cellobiohydrolase.
\end{abstract}

Kata kunci: endo-glucanase; cellobiohydrolase; kitosan; hidrolisis 
How to Cite This Article: Rokhati, N., Pramudono, B., Istirokhatun, T., Sulchan, M., Dyah Ayu Kresnianingrum, D.A, dan Dewi, L.K., (2015), Hidrolisis Enzimatik Kitosan dengan Kombinasi Enzim Endo-Glucanase dan Cellobiohydrolase, Reaktor, 15(4), 261-267, http://dx.doi.org/10.14710/reaktor.15.4.261-267

\section{PENDAHULUAN}

Kitosan merupakan polisakarida alami yang nontoxic, biodegradable, dan biocompatible yang dihasilkan dari proses deasetilasi kitin yang terkandung didalam cangkang binatang invertebrata terutama golongan crustacea, seperti udang, kepiting, dan rajungan. Kitosan dapat dimanfaatkan secara luas di berbagai bidang industri seperti pada bidang nutrisi sebagai suplemen dan sumber serat (Majeti dan Kumar, 2000), pada bidang pangan sebagai pembentuk tekstur, emulsifier, penjernih minuman dan antimicrobial (Shahidi dan Abuzaytoun, 2005), pada bidang medis sebagai antitumor, bahan contact lens dan membran untuk dialisis darah (Shahidi dan Abuzaytoun, 2005), bidang lingkungan untuk water treatment (Honarkar dan Barikani, 2009), dan bidang pertanian untuk fertilizer dan fungisida (Rinaudo, 2006).

Penggunaan kitosan dalam bidang pangan dan medis sering dibatasi oleh kelarutannya yang rendah terutama pada $\mathrm{pH}$ di atas 7 dan viskositasnya yang tinggi. Hal ini disebabkan oleh tingginya berat molekul yang dimiliki kitosan. Oleh karena itu peningkatan kelarutan dan penurunan viskositas merupakan langkah penting dalam aplikasi kitosan. Langkah ini dapat dicapai dengan pengurangan berat molekul kitosan (Roncal dkk., 2007). Berat molekul juga sangat berpengaruh terhadap karakteristik kitosan dan turunannya seperti sifat rheologi, sifat mekanik, serta ukuran pori membran kitosan (Tsao dkk., 2011)

Metode untuk menurunkan berat molekul meliputi: depolimerisasi kimia dengan hidrolisis asam atau oksidatif-reduktif menggunakan $\mathrm{O}_{3}, \mathrm{NaNO}_{2}$, atau $\mathrm{H}_{2} \mathrm{O}_{2}$, depolimerisasi fisik dengan menggunakan ultrasonik, dan depolimerisasi menggunakan enzim. Hidrolisis kimia memiliki beberapa kelemahan, diantaranya menggunakan larutan kimia konsentrasi tinggi yang residunya akan mencemari lingkungan, membutuhkan reaktor yang kompleks, yield yang rendah, dan ukuran berat molekulnya sulit dikontrol (Tsao dkk., 2011). Depolimerisasi fisik membutuhkan peralatan yang khusus dan ukuran molekul yang dihasilkan tidak bisa dikontrol (Lin dkk., 2009). Metode enzimatis menawarkan keuntungan seperti kondisi operasi reaksi ringan, reaksi mudah dikontrol, spesifisitas tinggi, yield tinggi, dan tidak terdapat modifikasi cincin glukosa, serta ramah lingkungan (Roncal dkk., 2007).

Enzim spesifik untuk hidrolisis kitosan adalah Chitosanase. Harga enzim jenis ini mahal dan belum banyak tersedia di pasaran, sehingga menghambat penggunaanya dalam skala industri. Baru-baru ini beberapa enzim yang tidak spesifik telah digunakan untuk menghidrolisis kitosan, diantaranya adalah enzim cellulase (Lin dan Ma, 2003; Liu dkk., 2005), pektinase (Sardar dkk., 2003; Abd-Elmohdy dkk., 2010), pepsin (Roncal dkk., 2007), papain (Huang dkk., 2003; Lin dkk., 2002), protease (Li dkk., 2005), dan lipase (Lee dkk., 2008).

Pada penelitian ini dilakukan hidrolisis enzimatis menggunakan kombinasi enzim endoglucanase dan cellobiohydrolase. Dalam rangka meningkatkan kinerja proses hidrolisis kitosan, terdapat beberapa metode penambahan enzim yang dilakukan.

\section{METODE PENELITIAN \\ Bahan}

Kitosan yang dibeli dari PT Biotech Surindo, Cirebon, Indonesia (BM 1280 kDa, DD 80,4\%). Enzim endo-glucanase $(0,8 \mathrm{U} / \mathrm{mg})$, Cellobiohydrolase $(0,13 \mathrm{U} / \mathrm{mg})$ dan D-(+) glucose dari Sigma Aldrich. Asam asetat, $\mathrm{NaOH}(99 \%), \mathrm{HCl}(37 \%), \mathrm{KNa}$-Tartrat (99\%), $\mathrm{CuSO}_{4} .5 \mathrm{H}_{2} \mathrm{O}$ (99\%), dan Methylene Blue (MB) dari Merck. Aquadest dari Laboratorium Membrane Research Center (Mer-C).

\section{Alat}

Hidrolisis dilakukan pada labu leher tiga yang dilengkapi dengan pemanas waterbath, magnetic stirrer, dan pendingin balik (Gambar 1)

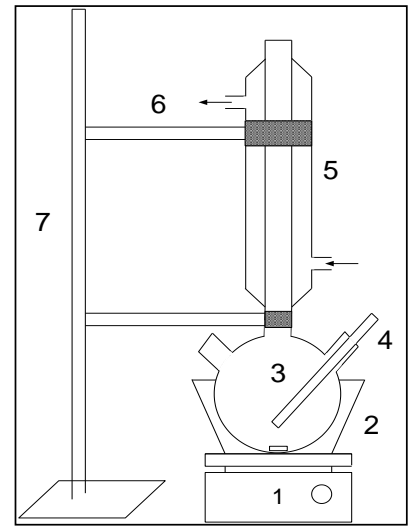

Keterangan :

1. Magnetic stirrer + heater

2. Waterbath

3. Labu leher tiga

4. Termometer

5. Pendingin balik

6. Klem

7. Statif

Gambar 1. Rangkaian alat hidrolisis

\section{Prosedur Penelitian \\ Hidrolisis kitosan}

Kitosan dilarutkan kedalam larutan asam asetat $1 \%$ (v/v) sehingga konsentrasinya $0,01 \mathrm{gr} / \mathrm{ml}$. Reaksi hidrolisis dilakukan pada temperatur $40^{\circ} \mathrm{C}$ dan $\mathrm{pH} 5$. Hidrolisis dihentikan dengan mendidihkan larutan selama 10 menit. Hasil hidrolisis diendapkan dengan menambahkan larutan $\mathrm{NaOH}$ pada $\mathrm{pH}$ 7-9. Solven diuapkan dengan menggunakan alat rotavap. Sampel yang sudah terpisahkan dari solvennya ditambahkan etanol, sampel disaring dengan kertas saring untuk memisahkan etanol. Sampel dioven selama 24 jam pada suhu $40^{\circ} \mathrm{C}$. 


\section{Uji gula reduksi}

Uji gula reduksi dilakukan untuk mengetahui banyaknya pemotongan rantai polimer (kitosan). Pemotongan rantai polimer akan menghasilkan gugus aldehid yang bersifat reduktor. Penentuan jumlah gula reduksi dilakukan dengan menggunakan metode LaneEynon (Eliasson, 2006). Banyaknya gula reduksi dalam sampel ditentukan dengan persamaan:

$$
\text { GulaReduksi }=\left[\frac{(\mathrm{F}-\mathrm{M}) \cdot \mathrm{N} \cdot \frac{\mathrm{B}}{5}}{\mathrm{~W}}\right]
$$

\section{Uji viskositas spesifik}

Penentuan viskositas spesifik dilakukan dengan menggunakan alat viskometer ostwald. Solven (larutan asam asetat 1\%) dimasukkan ke dalam viskometer kemudian waktu laju alirnya diukur. Setelah itu sampel larutan kitosan yang telah dihidrolisis dimasukkan kedalam viskometer dan waktu laju alirnya diukur. Nilai viskositas spesifik ditentukan dengan persamaan (Abd-Elmohdy dkk., 2010) :

$$
\eta_{\mathrm{sp}}=\frac{\eta-\eta_{0}}{\eta_{0}}=\frac{\mathrm{t}-\mathrm{t}_{0}}{\mathrm{t}_{0}}
$$

\section{Penentuan berat molekul}

Viskositas intrinsik dapat ditentukan dengan mengukur viskositas spesifik pada beberapa konsentrasi dan mengekstrapolasi grafik $\eta_{\mathrm{sp}} / \mathrm{c}$ versus $\mathrm{c}$ pada konsentrasi sama dengan nol. Analisis alternatif untuk mendapatkan hasil yang sama, digunakan persamaan (Pamies dkk., 2008):

$$
\ln \frac{\eta_{\mathrm{sp}}}{\mathrm{c}}=\ln [\eta]+\mathrm{kc}
$$

Setelah mengetahui viskositas instrinsik, maka bobot molekul kitosan dapat dihitung dengan menggunakan persamaan Mark Houwink (Kumar dkk., 2007):

$$
[\eta]=\mathrm{KM}_{\mathrm{w}}{ }^{\alpha}
$$

\section{Uji FTIR}

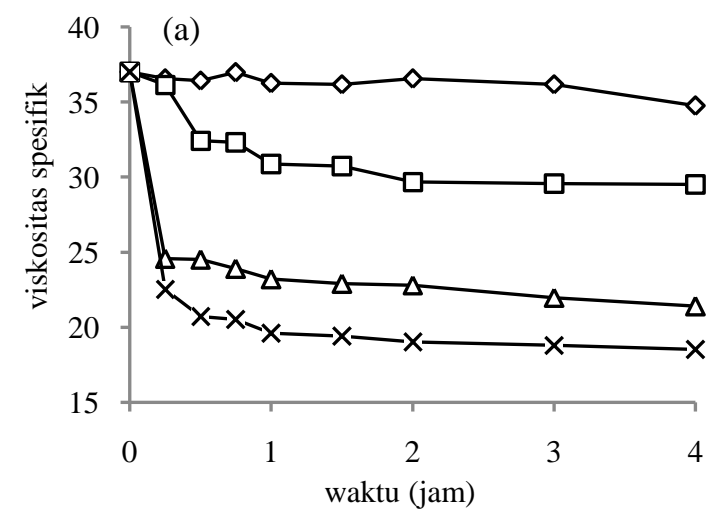

$$
\neg \text { no enzim } \quad \longrightarrow \text { - enzim 1:500 }
$$

Pengamatan terhadap gugus fungsional dilakukan dengan cara: sampel kitosan berbentuk powder dicampur dengan $\mathrm{KBr}$ powder kemudian dilakukan uji FTIR dengan IR Prestige 21 Shimadzu. Metode pembacaan menggunakan DRS-8000. Pada uji ini, dibandingkan antara spektrum dari kitosan awal, hasil hidrolisis dengan menggunakan enzim endoglucanase, dan hasil hidrolisis dengan enzim cellobiohydrolase.

\section{HASIL DAN PEMBAHASAN \\ Hidrolisis Kitosan dengan Enzim Endo-glucanase}

Hidrolisis kitosan dengan menggunakan enzim endo-glucanase dilakukan pada suhu $40^{\circ} \mathrm{C}$ dan $\mathrm{pH} 5$. Gambar 2(a) dan Gambar 2(b) menunjukkan pengaruh waktu hidrolisis pada berbagai rasio enzim : substrat $(\mathrm{g} / \mathrm{g})$ terhadap viskositas dan gula reduksi.

Perubahan viskositas larutan mencerminkan perubahan derajat polimerisasi rantai linier chitosan, oleh karena itu laju degradasi kitosan dapat dipelajari melalui pengukuran viskositas kitosan (Li dkk., 2007). Gambar 2(a) menunjukkan bahwa hidrolisis enzim endo-glucanase mengakibatkan penurunan viskositas larutan kitosan cukup besar selama 15 menit awal hidrolisis. Penurunan viskositas yang cukup besar disebabkan oleh penurunan berat molekul yang cukup besar yang diakibatkan oleh pemotongan rantai polimer terjadi pada bagian tengah polimer. Fenomena seperti ini menandakan bahwa enzim endo-glucanase merupakan endo-action (Lynd dkk., 2002). Setelah hidrolisis selama 1 jam laju degradasi melambat, yang kemungkinan karena adanya inhibisi/penghambat aktifitas enzim oleh produk akhir.

Gambar 2(a) juga menunjukkan bahwa semakin besar rasio enzim: substrat maka penurunan viskositas larutan semakin besar. Bertambahnya rasio enzim: substrat pada hidrolisis kitosan, menyebabkan bertambah banyak enzim yang mengkatalis reaksi pemutusan ikatan glikosida pada rantai kitosan. Semakin banyak ikatan polimer yang terpotong maka semakin turun berat molekul dari kitosan, yang kemudian berpengaruh pada penurunan viskositas.

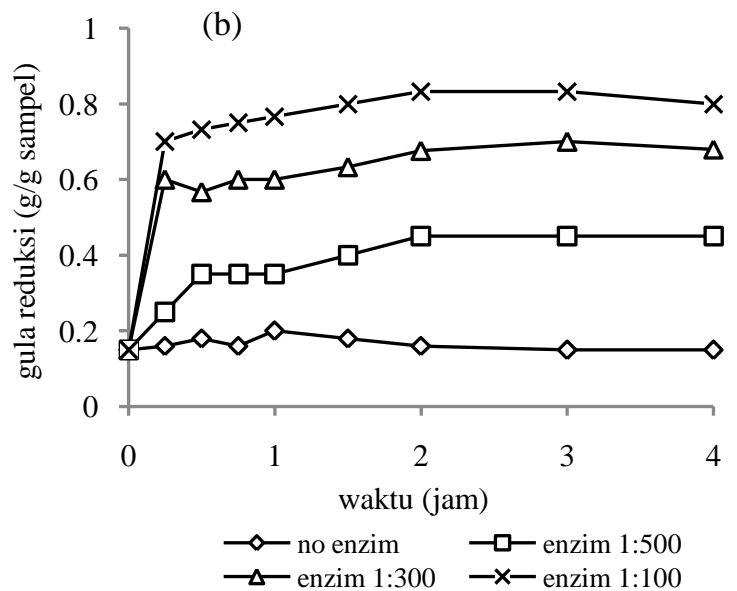

Gambar 2. Pengaruh waktu dan rasio enzim:substrat pada hidrolisis kitosan dengan menggunakan enzim endoglucanase terhadap (a) viskositas spesifik; (b) gula reduksi 

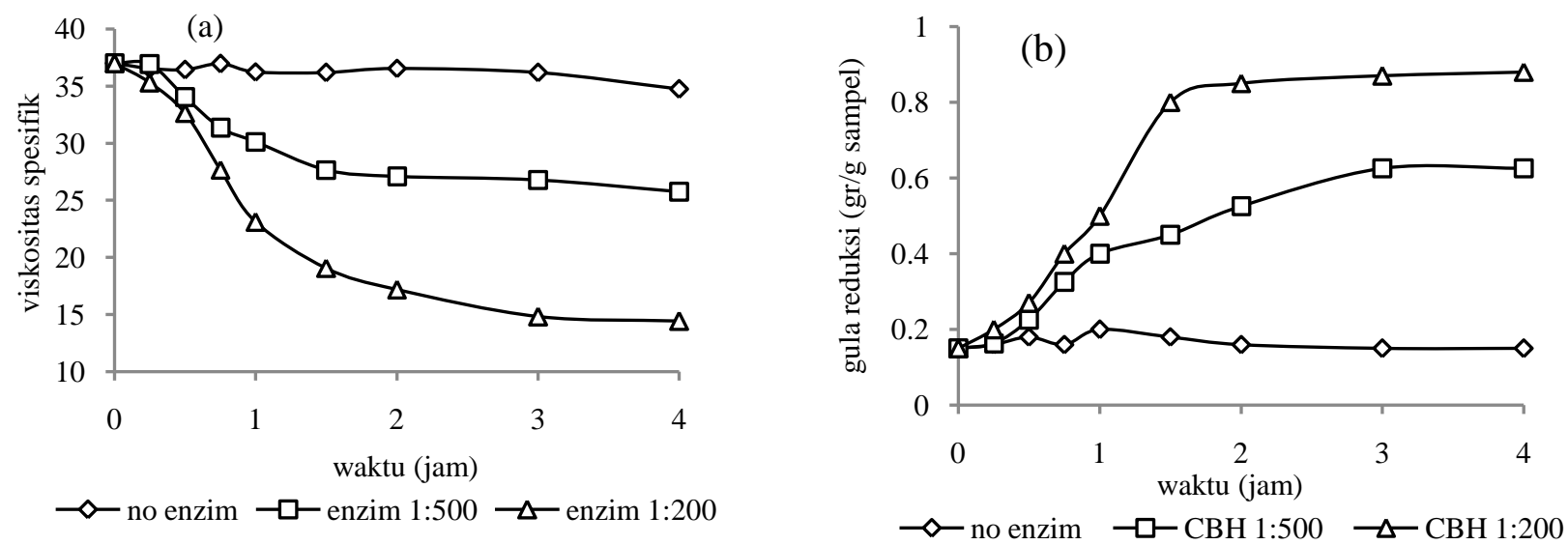

Gambar 3. Pengaruh waktu dan rasio enzim:substrat pada hidrolisis kitosan dengan menggunakan enzim cellobiohydrolase terhadap(a) viskositas spesifik; (b) gula reduksi

Setiap pemutusan ikatan glikosida pada rantai kitosan akan terbentuk satu gula reduksi dan satu gula non reduksi (Horn dan Eijsink, 2003). Pembentukan gula reduksi menunjukkan aktivitas enzim yang memotong ikatan glikosida pada kitosan. Semakin tinggi aktivitas enzim maka semakin tinggi pula gula reduksi yang dihasilkan. Penentuan kadar gula reduksi dapat digunakan untuk mengetahui peningkatan jumlah rantai kitosan yang terputus dari waktu ke waktu. Oleh karena itu semakin turun nilai viskositas larutan kitosan maka semakin tinggi kadar gula reduksi (Gambar 2(b)). Hasil hidrolisis kitosan selama 4 jam dengan enzim endo-glucanase memiliki nilai viskositas spesifik sebesar 18,5 (penurunan viskositas sebesar 50\%) dan kadar gula reduksi sebesar 0,8 g/g kitosan.

\section{Hidrolisis Kitosan dengan Enzim Cellobiohydrolase}

Hasil hidrolisis kitosan dengan enzim cellobiohydrolase $(\mathrm{CBH})$ pada suhu $40^{\circ} \mathrm{C}$ dan $\mathrm{pH} 5$ dengan variasi rasio enzim : substrat sebesar 1:200 dan 1:500 ditampilkan pada Gambar 3(a) dan 3(b). Hidrolisis kitosan dengan enzim $\mathrm{CBH}$ menghasilkan kitosan dengan viskositas spesifik yang lebih rendah dibandingkan dengan enzim endo-glucanase. Penurunan viskositas ini terjadi secara bertahap dari waktu ke waktu. Enzim CBH merupakan jenis enzim exo-cellulase yang memotong ikatan glikosida bagian tepi dari polimer. Hasil pemutusan ikatan glikosida oleh enzim exo-cellulase pada bagian tepi rantai dapat menghasilkan tetrasakarida atau disakarida (Andersen, 2007). Oleh karena itu, hasil hidrolisis kitosan oleh enzim ini memiliki viskositas spesifik yang lebih rendah. Hasil dari hidrolisis kitosan selama 4 jam dengan menggunakan enzim $\mathrm{CBH}$ memiliki nilai viskositas spesifik sebesar 14,42 dan kadar gula pereduksi sebesar $0,88 \mathrm{~g} / \mathrm{g}$ kitosan.
Hidrolisis Kitosan dengan Kombinasi Enzim Endoglucanase dan Cellobiohydrolase

Pada tahap ini dipelajari pengaruh kombinasi penambahan enzim endo-glucanase dan cellobiohydrolase $(\mathrm{CBH})$ terhadap hasil hidrolisis kitosan. Lima metode penambahan enzim, yaitu hanya menggunakan enzim endo-glucanase dengan rasio enzim:substrat sebesar 1:100 (metode A), hanya menggunakan enzim $\mathrm{CBH}$ dengan ratio enzim:substrat sebesar 1:200 (metode B), pencampuran enzim endoglucanase dan $\mathrm{CBH}$ dengan rasio endo-glucanase :CBH:substrat sebesar 1:1/2: 200 (metode C), setelah proses hidrolisis dengan enzim $\mathrm{CBH}$ selama 15 menit kemudian ditambahkan enzime endo-glucanase (metode D), dan setelah proses hidrolisis dengan enzim endo-glucanase selama $1 \mathrm{jam}$ kemudian ditambahkan enzime $\mathrm{CBH}$ (metode E). Gambar 4 menunjukkan pengaruh waktu dan metode penambahan enzim terhadap viskositas larutan hasil hidrolisis.

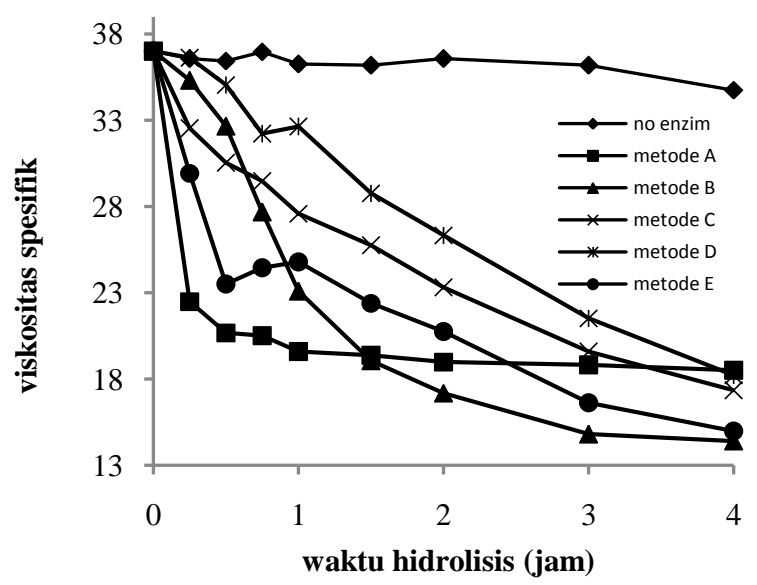

Gambar 4. Pengaruh waktu dan metode penambahan enzim pada hidrolisis kitosan 
Hidrolisis kitosan dengan menggunakan metode $\mathrm{C}$ menghasilkan penurunan nilai viskositas secara bertahap dari awal hingga reaksi berlangsung selama 4 jam. Kedua enzim tersebut dapat bekerja bersama-sama atau secara bertahap dalam menguraikan rantai kitosan menjadi molekul yang lebih sederhana. Hidrolisis kitosan selama 4 jam dengan metode ini menghasilkan kitosan dengan viskositas spesifik sebesar 17,34.

Penurunan nilai viskositas dari hidrolisis kitosan dengan menggunakan metode $\mathrm{D}$ juga terjadi secara bertahap. Pada menit ke 45 hingga 60 nilai viskositas mengalami kenaikan, hal ini kemungkinan disebabkan oleh kompetisi dari kedua enzim. Kompetisi antara enzim exocellulase dan endocellulase untuk berebut sisi aktif dapat terjadi karena exocellulase tidak hanya mengikat sisi aktif pada bagian luar rantai, tetapi juga dapat mengikat sisi aktif yang lebih dalam (Kyriacou dkk., 1989; Andersen, 2007). Hidrolisis kitosan selama 4 jam dengan enzim ini menghasilkan kitosan dengan viskositas spesifik sebesar 18,23.

Hidrolisis kitosan menggunakan enzim $\mathrm{CBH}$ kemudian endo-glucanase (metode E) menunjukkan bahwa viskositas turun sampai pada menit ke 30 kemudian mengalami sedikit kenaikan sampai pada menit ke 60. Kenaikan viskositas ini terjadi oleh adanya penurunan aktivitas enzim karena hasil hidrolisis merupakan produk kitosan bermolekul lebih rendah yang memiliki struktur sama dengan substrat awal. Keberadaan produk dalam kondisi tertentu justru akan menjadi inhibitor yang akan menghambat kinerja enzim sehingga dapat terjadi rekombinasi dua atau lebih produk hasil hidrolisis pada sisi aktif enzim (Li, dkk., 2005; Rokhati, dkk., 2013). Selanjutnya viskositas mengalami penurunan kembali setelah penambahan enzim endo-glucanase. Hidrolisis kitosan selama 4 jam dengan enzim ini menghasilkan kitosan dengan viskositas spesifik sebesar 14,97.

\section{Karakteristik Produk Hidrolisis Kitosan}

Perbedaan karakteristik kitosan sebelum hidrolisis dan setelah hidrolisis ditunjukkan pada Tabel 1. Viskositas dan berat molekul (BM) dari kitosan setelah hidrolisis mengalami penurunan yang signifikan. Sedangkan kelarutan kitosan hasil hidrolisis mengalami kenaikan. Viskositas terendah diperoleh pada hidrolisis enzim $\mathrm{CBH}$, tapi kelarutan tertinggi diperoleh pada hidrolisis campuran enzim

Hal ini menunjukkan bahwa hidrolisis kitosan oleh enzim $\mathrm{CBH}$ menghasilkan produk kitosan dengan berat molekul yang kurang seragam (campuran berat molekul rendah dan tinggi), sedangkan hidrolisis kitosan oleh campuran enzim endo-glucanase dan $\mathrm{CBH}$ menghasilkan kitosan dengan berat molekul yang relatif lebih seragam. Alasan ini diperkuat dengan hasil gula reduksi kitosan dari hidrolisis enzim $\mathrm{CBH}$ yang lebih besar dibanding dengan kitosan dari hidrolisis enzim endo-glucanase dan $\mathrm{CBH}$.
Tabel 1. Perbandingan karakteristik kitosan sebelum dan setelah hidrolisa

\begin{tabular}{lcccc}
\hline \multirow{2}{*}{$\begin{array}{l}\text { Kondisi } \\
\text { operasi }\end{array}$} & $\begin{array}{c}\text { Viskositas } \\
\text { spesifik }\end{array}$ & $\begin{array}{c}\mathrm{BM} \\
(\mathrm{kDa})\end{array}$ & $\begin{array}{c}\text { Gula reduksi } \\
(\mathrm{g} / \mathrm{g} \text { kitosan })\end{array}$ & $\begin{array}{c}\text { Kelarutan } \\
\mathrm{g} / 100 \mathrm{ml})\end{array}$ \\
\hline Kitosan & 37,00 & 1280 & 0,15 & 0,08 \\
awal & & & & 0,37 \\
Metode A & 18,50 & 447 & 0,80 & 0,30 \\
Metode B & 14,42 & 328 & 0,88 & 0,40 \\
Metode C & 17,34 & 435 & 0,80 & 0,34 \\
Metode D & 18,23 & 340 & 0,75 & 0,30 \\
Metode E & 14,97 & 392 & 0,85 & \\
\hline
\end{tabular}

Hasil analisis FTIR (Gambar 5) terlihat bahwa terdapat puncak absorbansi pada 3440,96 $\mathrm{cm}^{-1}$; $3444,81 \mathrm{~cm}^{-1} ; 3435,17 \mathrm{~cm}^{-1}$ yang menunjukkan adanya N-H stretch pada kitosan awal, kitosan hasil hidrolisis endo-glucanase, dan kitosan hasil hidrolisis CBH. Absorbansi 2879,67 cm ; $2931,75 \mathrm{~cm}^{-1}$; $2925,96 \mathrm{~cm}^{-1}$ mengindikasikan adanya $\mathrm{C}-\mathrm{H}$ stretch pada kitosan awal, kitosan hasil hidrolisis endoglucanase dan kitosan hasil hidrolisis $\mathrm{CBH}$ (Stuart, 2004).

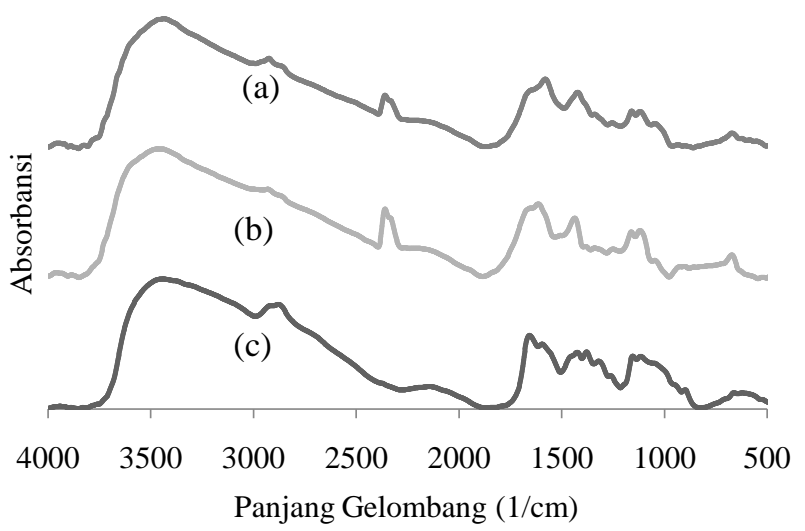

Gambar 5. Hasil analisis FTIR: (a) kitosan hasil hidrolisis cellobiohydrolase; (b) kitosan hasil hidrolisis endo-glucanase; (c) kitosan awal

Absorbansi $2360.82 \mathrm{~cm}^{-1}$ pada kitosan hasil hidrolisis endo-glucanase dan $\mathrm{CBH}$ mengindikasikan adanya O-H stretch pada asam karboksilat dikarenakan pencucian kitosan yang kurang sempurna sehingga masih ada asam asetat yang tersisa. Adanya $\mathrm{N}-\mathrm{H}$ bend ditunjukkan absorbansi $1595,08 \mathrm{~cm}^{-1}$ dan $1656,8 \mathrm{~cm}^{-1}$ pada kitosan awal; $1614,37 \mathrm{~cm}^{-1}$ pada kitosan hasil hidrolisis endo-glucanase; dan 1579,65 $\mathrm{cm}^{-1}$ pada kitosan hasil hidrolisis CBH. Absorbansi $1321,19 \mathrm{~cm}^{-1} ; \quad 1379,05 \quad \mathrm{~cm}^{-1} ; 1425,34 \mathrm{~cm}^{-1}$ mengindikasikan adanya gugus $-\mathrm{CH}_{2}$ bend dan $-\mathrm{CH}_{3}$ bend pada kitosan awal, 1436,92 $\mathrm{cm}^{-1}$ menunjukkan adanya $-\mathrm{CH}_{2}$ bend pada kitosan hasil hidrolisis endoglucanase, dan 1423,41 $\mathrm{cm}^{-1}$ menunjukkan adanya $\mathrm{CH}_{2}$ pada kitosan hasil hidrolisis $\mathrm{CBH}$. Adanya C-N stretch ditunjukkan absorbansi $1114,80 \mathrm{~cm}^{-1}$ dan $1153,38 \mathrm{~cm}^{-1}$ pada kitosan awal, $1118,66 \mathrm{~cm}^{-1}$ dan 
$1161,1 \mathrm{~cm}^{-1}$ pada kitosan hasil hidrolisis endoglucanase, serta $1118,66 \mathrm{~cm}^{-1}$ dan $1159,17 \mathrm{~cm}^{-1}$ pada kitosan hasil hidrolisis $\mathrm{CBH}$.

\section{KESIMPULAN}

Hidrolisis kitosan $0,01 \mathrm{~g} / \mathrm{ml}$ pada suhu $40^{\circ} \mathrm{C}$, $\mathrm{pH} 5$, menggunakan enzim endo-glucanase dengan rasio enzim:substrat sebesar 1:100 bekerja efektif selama waktu hidrolisis 15 menit, sedangkan enzim $\mathrm{CBH}$ dengan rasio enzim:substrat sebesar 1:200 dapat bekerja efektif dengan waktu hidrolisis 1 jam. Hidrolisis kitosan dengan enzim $\mathrm{CBH}$ memiliki viskositas terendah dan kadar gula reduksi terbesar, tetapi kelarutan tertinggi diperoleh pada hidrolisis campuran enzim endo-glucanase dan $\mathrm{CBH}$. Hal ini menunjukkan bahwa hidrolisis kitosan oleh enzim $\mathrm{CBH}$ menghasilkan produk kitosan dengan berat molekul yang kurang seragam (campuran berat molekul rendah dan tinggi), sedangkan hidrolisis kitosan oleh campuran enzim endo-glucanase dan $\mathrm{CBH}$ menghasilkan kitosan dengan berat molekul yang relatif lebih seragam. Hidrolisis kitosan dengan menggunakan campuran enzim endo-glucanase dan $\mathrm{CBH}$ tersebut dapat menurunkan berat molekul kitosan dari $1280 \mathrm{kDa}$ menjadi $435 \mathrm{kDa}$.

\section{UCAPAN TERIMAKASIH}

Ucapan terimakasih kepada Ditlitabmas Dikti atas bantuan dana penelitian Unggulan Perguruan Tinggi tahun anggaran 2015, Nomor : 13829/UN7.5.1/PG/2015.

\section{DAFTAR NOTASI}

$\mathrm{F}=$ Larutan glukosa anhidrat yang dibutuhkan untuk menitrasi 5 mlfehling $\mathrm{A}+5 \mathrm{ml}$ fehling B + 15 ml larutan glukosa anhidrat

$\mathrm{M}=$ Larutan glukosa anhidrat yang dibutuhkan untuk menitrasi $5 \mathrm{ml}$ fehling $\mathrm{A}+5 \mathrm{ml}$ fehling $\mathrm{B}+15 \mathrm{ml}$ larutan glukosa standar $+5 \mathrm{ml}$ sampel

$\mathrm{N}=$ Glukosa anhidrat $(\mathrm{g} / \mathrm{ml})$

$\mathrm{B}=$ Volume larutan hidrolisis $(\mathrm{ml})$

$\mathrm{W}=$ Berat kitosan $(\mathrm{g})$

$\eta_{s p}=$ Viskositas spesifik

$\eta \quad=$ Viskositas sampel

$\eta_{0}=$ Vikositas solven

$t \quad=$ Waktu laju alir sampel (detik)

$t_{o}=$ Waktu laju alir solven (detik)

$[\eta]=$ Viskositas intrinsik

$\mathrm{K}=$ Konstante $\left(3.5 \times 10^{-4}\right)$

$\mathrm{M}_{\mathrm{w}}=$ Berat molekul

$\alpha=$ Konstante (0.76)

\section{DAFTAR PUSTAKA}

Abd-Elmohdy, F.A., El-Sayed, Z., Essam, S., and Hebeish, A., (2010), Controlling chitosan molecular weight via bio-chitosanolysis, Carbohydrate Polymers, 82(3), pp. 539-542.
Andersen, N., (2007), Enzymatic hydrolysis of cellulose, BioCentrum, Technical University of Denmark.

Eliasson, A., (2006), Carbohydrates in Food, $2^{\text {nd }}$ edition, New York: CRC Press Taylor \& Francis Group.

Honarkar, H. and Barikani, M., (2009), Applications of biopolymers I: chitosan, Published online: Springer-Verlag.

Horn, S.J. and Eijsink, V.G.H., (2003), A reliable reducing sugar end assay for chito-oligosaccharides, Carbohydrate Polymers, 56, pp. 35-39.

Huang, Y.C., Li, L., Guo, S.Y., and Cai, M.Y., (2003), Characteristics of chitosan degradation by papain, Journal of South China University of Technology (Nature Science), 31, pp. 71-75

Kyriacou, A., Neufeld, R.J., and Mackenzie, C.R., (1989), Reversibility and competition in the adsorption of Trichoderma-Ressei cellulase components, Biotechnol, 33, pp. 631-637.

Kumar, A.B.V., Varadaraj, M.C., Gowda, L.R., and Tharanathan, R.N., (2007), Low molecular weight chitosans-Preparation with the aid of pronase, characterization and their bactericidal activity towards Bacillus cereus and Escherichia coli, Biochimica et Biophysica Acta, 1770, pp. 495-505.

Lee, D.X., Xia, W.S., and Zhang, J.L., (2008), Enzymatic preparation of chitooligosaccharides by commercial lipase, Food Chemistry, 111(2), pp. 291295 .

Li, J., Du, Y., Yang, J., Feng, T., Li,A., and Chen, P., (2005), Preparation and characterisation of low molecular weight chitosan and chitooligomers by a commercial enzyme, Polymer Degradation and Stability, 87(3), pp. 441-448.

Li, J., Du, Y., and Liang, H., (2007), Influence of molecular parameters on the degradation of chitosan by a commercial enzyme, Polymer Degradation and Stability, 92, pp. 515-524.

Lin, Q. and Ma, K.L., (2003), Study of Catalytic Hydrolysis of Chitosan by Cellulase, China Surfactant Detergent and Cosmetics, 33, pp. 22-25.

Lin, H., Wang, H., Xue, C., and Ye, M., (2002), Preparation of chitosan oligomers by immobilized papain, Enzyme and Microbial Technology, 31(5), pp. 588-592.

Lin, S., Lin, Y.C., and Chen, H., (2009), Low molecular weight chitosan prepared with the aid of cellulase, lysozyme and chitinase: Characterisation 
and antibacterial activity, Food Chemistry, 116, pp. 47-53.

Liu, Y.J., Jiang, Y., Feng, Y.F., and Han, D., (2005), Study on the chitosan hydrolysis catalyzed by special cellulase and preparation of chitooligosaccharide, Journal of Functional Polymers, 18, pp. 325-329.

Lynd, L.R., Weimer, P.J., Zyl, W.H.V., and Pretorius, I.S., (2002), Microbial cellulose utilization: fundamentals and biotechnology, Microbiol. Mol. Biol., 66, pp. 507-560.

Majeti, N.V. and Kumar, R., (2000), A review of chitin and chitosan applications, Reactive \& Functional Polymers, 46, pp. 1-27

Pamies, R., Cifre, J.G.H., Martínez, M.C.L., and Torre, J.T., (2008), Determination of intrinsic viscosities of macromolecules and nanoparticles: Comparison of single-point and dilution procedures, Colloid Polym Sci., 286, pp. 1223-1231.

Rinaudo, M., (2006), Chitin and chitosan: Properties and Applications, Prog. Polym. Sci., 3, pp. 603-632.

Rokhati, N., Widjajanti, P., Pramudono, B., and Susanto, H., (2013), Performance comparison of $\alpha$ and $\beta$-amylases on chitosan hydrolysis, ISRN Chemical Engineering, Article ID 186159, 5 pages
Roncal, T., Oviedo, A., Armentia, I.L., Fernande, L., and Villaran, M.C., (2007), High yield production of monomer-free chitosan oligosaccharides by pepsin catalyzed hydrolysis of a high deacetylation degree chitosan, Carbohydrate Research, 342, 2750-2756.

Sardar, M., Roy, I., and Gupta, M.N., (2003), A smart bioconjugate of alginate and pectinase with unusual biological activity toward chitosan, Biotechnol. Prog, 19 , pp. $1654-1658$.

Shahidi, F. and Abuzaytoun, R., (2005), Chitin, Chitosan, And Co-Products: Chemistry, Production, Applications, And Health Effects, Advances In Food And Nutrition Research, 49, pp. 93-135.

Stuart, B.H., (2004), Infrared spectroscopy: fundamentals and applications, John Wiley \& Sons, Ltd, The Atrium, Southern Gate, Chicheter, West Sussex PO19 8SQ, England.

Tsao, C.T., Chang, C.H., Lin, Y.Y., Wu, M.F.,Han, J.L., and Hsieh, K.H., (2011), Kinetic study of acid depolymerization of chitosan and effects of low molecular weight chitosan on erythrocyte rouleaux formation, Carbohydrate research, 346(1), pp. 94102. 